\title{
Assessing stable carbon isotope disequilibrium in late Pleistocene buried soils of the Great Plains, USA, using a state factor approach
}

\author{
A.L. LAYZELL*, G.A.LUdVIGSON, J.J. SMITH AND R.D.
} MANDEL

Kansas Geological Survey, 1930 Constant Ave., Lawrence, KS 66047, USA (*correspondence: alayzell@ku.edu)

Buried soils serve as important archives of paleoenvironmental information and landscape history. In particular, the stable carbon isotope $\left(\delta^{13} \mathrm{C}\right)$ compositions of soil organic matter and pedogenic carbonates in buried soils have proved to be valuable proxies for reconstructing late Quaternary ecological and climatic change. Here, we investigate a series of buried soils from central Great Plains, USA, that date to ca. 28-48 ka (Marine Isotope Stage [MIS] 3). $\delta^{13} \mathrm{C}$ analyses were formed on bulk pedogenic carbonates $\left(\delta^{13} \mathrm{C}_{\text {carb }}\right)$ and co-occurring soil organic matter $\left(\delta^{13} \mathrm{C}_{\mathrm{SOM}}\right)$ to reconstruct late-Quaternary bioclimatic change in the region.

Results indicate a unique decoupling between $\delta^{13} \mathrm{C}_{\text {carb }}$ and $\delta^{13} \mathrm{C}_{\text {SOM }}$ in the buried soils. $\Delta{ }^{13} \mathrm{C}$ values $\left(\delta^{13} \mathrm{C}_{\text {carb }}-\right.$ som $)$ are 2 to 7 per mil higher than expected equilibrium values in the $\mathrm{Bk}$ horizons. In contrast, $\Delta{ }^{13} \mathrm{C}$ values are 1 to 5 per mil lower than expected equilibrium values in the Ak horizons. Using a state factor approach to soil formation allows for the establishment of multiple working hypotheses regarding the influence of climate, vegetation, parent material, and time on the observed trends in $\delta^{13} \mathrm{C}$ values. In particular, we consider the effect of temperature, aridity, seasonality, and $\mathrm{pCO}_{2}$ levels during MIS 3 as well as potential changes in parent material sources, phases of carbonate growth, and diagenetic overprinting over time. A variety of techniques are utilized, including strontium isotope $\left({ }^{87} \mathrm{Sr} /{ }^{86} \mathrm{Sr}\right)$ and particle-size analyses together with petrographic and cathodoluminescence imaging of carbonate components.

Given that pedogenic carbonates are widely used as paleoenvironmental proxies, our results highlight the necessity of screening pedogenic carbonates for isotopic equilibrium as well as understanding landscape histories when interpreting isotopic trends. 